\title{
EFFECTIVENESS OF IMPLEMENTATION OF PROBLEM BASED LEARNING MODELS TO IMPROVE STUDENTS' MATHEMATICAL LEARNING OUTCOMES IN XI-MIPA SMA NEGERI 8 PEKANBARU
}

\section{EFEKTIVITAS PENERAPAN MODEL PROBLEM BASED LEARNING TERHADAP PENINGKATAN HASIL BELAJAR MATEMATIKA SISWA KELAS XI-MIPA SMA NEGERI 8 PEKANBARU}

\author{
Restu Prabowo, Atma Murni, Zulkarnain \\ Pendidikan Matematika, Universitas Riau \\ Email : restuprabowo25@gmail.com
}

Submitted: (3 Mei 2020); Accepted: (27 Mei 2020);

Published: (31 Mei 2020)

\begin{abstract}
The background of this research was the low ability of student' mathematical learning outcomes of SMA Negeri 8 Pekanbaru. The purposes of this research were: 1) to find the significance of students' mathematical learning outcomes who study through Problem Based Learning (PBL) model with student who study through conventional learning with scientific approach; (2) to examine the improvement of students' mathematical learning outcomes who study through PBL model and students who study through conventional learning with scientific approach in class XI-MIPA SMA Negeri 8 Pekanbaru. This research was an experimental research (quasi experiment) with The Nonequivalent Pretest-Posttest Control Group Design. The population of this research is all students of class XI-MIPA SMA Negeri 8 Pekanbaru. Sample of this research consist of two classes, class XI-MIPA 4 as experiment class and XI-MIPA 3 as control class. The data of this research were student's mathematical learning outcomes from pretest-posttest. Students' mathematical learning outcomes were analyzed using independent sample t-test which was preceded by normality test and homogeneity of variances test. The result of this research shows that the improvement of students' mathematical learning outcomes who study through PBL model is higher than students who study through conventional learning with scientific approach.
\end{abstract}

Keywords: Problem Based Learning model, Mathematical learning outcomes, Scientific approach, Conventional learning

\section{PENDAHULUAN}

Matematika adalah mata pelajaran yang diajarkan kepada siswa dari jenjang sekolah dasar sampai sekolah menengah. Sebagai salah satu disiplin ilmu, matematika memiliki tujuan pembelajaran. Adapun tujuan pembelajaran matematika adalah agar siswa memiliki kemampuan antara lain: (1) memahami konsep matematika, menjelaskan keterkaitan antar konsep dan mengaplikasikan konsep atau algoritma secara luwes, akurat, efisien, dan tepat dalam pemecahan masalah; (2) menggunakan penalaran pada pola dan sifat, melakukan manipulasi matematika dalam membuat generalisasi, menyusun bukti, atau menjelaskan gagasan dan pernyataan matematika; (3) memecahkan masalah yang meliputi kemampuan memahami masalah, merancang model matematika, menyelesaikan model dan menafsirkan solusi yang diperoleh; (4) mengkomunikasikan gagasan dengan simbol, tabel, diagram, atau media lain untuk memperjelas keadaan atau masalah; (5) memiliki sikap menghargai kegunaan matematika dalam kehidupan, yaitu memiliki rasa ingin tahu, perhatian, dan minat dalam mempelajari matematika, serta sikap ulet dan percaya diri dalam pemecahan masalah; (6) memiliki sikap dan perilaku yang sesuai dengan nilai-nilai dalam matematika dan pembelajarannya; (7) melakukan kegiatankegiatan motorik yang menggunakan pengetahuan matematika; (8) menggunakan alat peraga sederhana maupun hasil teknologi 
untuk melakukan kegiatan-kegiatan matematika (Kemendikbud, 2014). Tercapainya tujuan pembelajaran matematika tersebut dapat dilihat dari keberhasilan dan ketuntasan hasil belajar matematika yang diperoleh siswa setelah mengikuti proses pembelajaran matematika. Siswa dinyatakan tuntas belajar apabila nilai yang diperoleh telah mencapai Kriteria Ketuntasan Minimum (Kemendiknas, 2007).

Kualitas pendidikan di Indonesia dapat dikatakan masih rendah. Hasil survei yang dilakukan oleh United Nations Development Programme (UNDP) yang mengukur nilai Indeks Pembangunan Manusia (IPM) suatu negara berdasarkan angka harapan hidup saat lahir, angka partisipasi sekolah dan pendapatan per kapita pada tahun 2018 menunjukkan bahwa Indonesia berada pada peringkat 116 dari 189 negara. Indonesia masih termasuk dalam kategori menengah dalam pembangunan manusia (medium human development) dengan nilai IPM 0,694. Pada bidang pendidikan, ketidaksetaraan distribusi pendidikan sebesar $20,8 \%$. Hal ini menyebabkan pembangunan sumber daya manusia melalui bidang pendidikan di Indonesia belum maksimal.

Kualitas pendidikan Indonesia yang belum maksimal ditandai dengan lemahnya kemampuan literasi dan numerasi. Berdasarkan hasil survei lembaga internasional Organization for Economic Co-operation and Development (OECD) dalam bidang kemampuan orang dewasa (survey of adult skill) yaitu Programme for the International Assessment of Adult Competencies (PIAAC) mengukur kemampuan orang dewasa pada tingkat literasi, kemampuan numerasi, dan kemampuan penyelesaian masalah. Hasil survei PIAAC terakhir di tahun 2016 menunjukkan bahwa $60 \%$ penduduk Indonesia usia dewasa berada pada kategori di bawah level satu untuk kemampuan numerasi (survei pada 7.229 orang usia 16-65 tahun). Kemampuan numerasi di bawah level satu merupakan kategori yang paling rendah, yaitu hanya mampu menyelesaikan masalah matematika sederhana (OECD, 2018).

Senada dengan hasil survei UNDP dan OECD, hasil belajar matematika siswa-siswa pada jenjang sekolah menengah atas
(SMA/MA) pada Ujian Nasional (UN) di Indonesia juga mengalami penurunan dalam kurun waktu dua tahun terakhir. Pada tahun 2018, nilai rata-rata UN SMA/MA di Indonesia mengalami penurunan sebesar 4,67 dibandingkan tahun 2017. Pada tahun 2017, nilai rata-rata UN SMA/MA adalah sebesar 41,92 sedangkan pada tahun 2018 nilai ratarata UN SMA/MA turun adalah 37,25 (Kemendikbud, 2018). Rendahnya hasil belajar matematika siswa SMA/MA di kota Pekanbaru juga dapat dilihat dari penurunan rata-rata nilai UN Matematika. Pada tahun 2018, rata-rata nilai UN Matematika tingkat SMA/MA kota Pekanbaru sebesar 40,33. Sementara itu, di tahun 2019 terjadi penurunan rata-rata nilai UN Matematika tingkat SMA/MA menjadi 37,52 .

Penurunan rata-rata nilai UN Matematika juga terjadi di salah satu sekolah favorit di Pekanbaru yaitu SMA Negeri 8. Berdasarkan data yang diperoleh, rata-rata nilai UN matematika di SMA Negeri 8 Pekanbaru mengalami penurunan selama tiga tahun terakhir. Pada tahun 2016, nilai rata-rata UN sebesar 78,33. Pada tahun 2017 mengalami penurunan menjadi 71,04 , dan kembali menurun pada tahun 2018 menjadi 70,17 . Penurunan yang cukup signifikan terjadi pada tahun 2017 yakni sebesar 7,29 dari tahun sebelumnya. Hal ini dapat dijadikan indikator bahwa hasil belajar matematika siswa di SMA Negeri 8 Pekanbaru masih perlu ditingkatkan.

Menyikapi hal tersebut, peneliti melakukan wawancara kepada siswa kelas XIMIPA SMA Negeri 8 Pekanbaru dan didapatkan informasi bahwa: (1) pelajaran matematika membosankan dan tidak menarik, sehingga siswa mengobrol dengan temannya dan mengerjakan pekerjaan lain yang menyenangkan dan pada akhirnya mereka tidak mengerti dengan materi yang diajarkan; (2) siswa tidak mau bertanya selama proses pembelajaran disebabkan adanya perasaan malu dan adanya perasaan takut dimarahi oleh guru.

Peneliti juga melakukan pengamatan terhadap proses pembelajaran matematika yang berlangsung di kelas XI-MIPA. Hasil pengamatan menunjukkan bahwa guru tidak mengajak siswa untuk aktif dalam proses 
pembelajaran dan guru juga belum sepenuhnya menerapkan kegiatan pembelajaran berdasarkan tuntutan Kurikulum 2013 yang sebagaimana tertuang dalam Permendikbud No. 22 Tahun 2016. Pada saat proses pembelajaran tepatnya pada kegiatan pendahuluan, guru belum melakukan apersepsi dan menyampaikan tujuan pembelajaran yang akan dicapai. Di akhir pembelajaran guru juga belum mengajak siswa untuk dapat merangkum materi yang telah dipelajari. Akibatnya pembelajaran belum tuntas sehingga belum diketahui manfaat dari pembelajaran tersebut.

Proses pembelajaran matematika yang terjadi di kelas XI-MIPA SMA Negeri 8 Pekanbaru masih berpusat pada guru dimana komunikasi dilakukan hanya satu arah dari guru ke siswa dan siswa kurang aktif selama proses pembelajaran. Hal ini berdampak pada hasil ulangan harian siswa yang masih sangat rendah. Pada salah satu kelas XI-MIPA di SMA Negeri 8 Pekanbaru dengan materi persamaan trigonometri hanya 5 dari 36 $(13,89 \%)$ siswa yang mencapai KKM yang telah ditetapkan sekolah yaitu 75 . Ini berarti masih terdapat kesenjangan antara hasil belajar yang diharapkan dengan hasil belajar yang dicapai oleh siswa karena banyak siswa yang nilainya di bawah KKM yang ditetapkan sekolah.

Berdasarkan informasi yang diperoleh, peneliti menyimpulkan bahwa penyebab rendahnya hasil belajar matematika adalah siswa kurang dilibatkan dalam proses pembelajaran dan tidak memahami hubungan materi yang dipelajari dengan permasalahan nyata dalam kehidupan sehari-hari sehingga dapat dikatakan hasil belajar pada siswa masih sangat rendah.Banyak siswa yang hanya dapat menyelesaikan soal rutin yang diberikan guru. Siswa kesulitan ketika diberikan soal non rutin. Pembelajaran yang dilakukan belum mengenalkan kepada siswa hubungan antara konsep matematika dengan situasi nyata dalam kehidupan sehari-hari sehingga pembelajaran menjadi kurang bermakna.

Menurut Heinich (Pribadi, 2010), proses pembelajaran akan berlangsung efektif jika siswa terlibat aktif dalam tugas-tugas bermakna dan berinteraksi dengan materi pelajaran secara intensif. Proses pembelajaran dapat disebut sukses apabila memenuhi kriteria sebagai berikut, yakni siswa melakukan interaksi dengan sumber belajar secara intensif, melakukan latihan untuk penguasaan kompetensi, memperoleh umpan balik segera setelah melakukan proses belajar, menyajikan permasalahan nyata sehingga nantinya siswa dapat menerapkan kemampuan dalam konteks nyata, dan melakukan interaksi dalam memperoleh pengetahuan dan keterampilan.

Untuk dapat meningkatkan hasil belajar matematika siswa, guru dapat memberikan pengalaman belajar dengan mendesain proses pembelajaran. Guru mendesain pembelajaran dengan memberikan permasalahan yang melibatkan keterampilan berpikir siswa dan melibatkan proses menganalisis berdasarkan permasalahan yang sebenarnya. Salah satu model pembelajaran yang dapat diterapkan adalah Problem Based Learning (PBL) atau pembelajaran berbasis masalah (Nafiah dan Suyanto, 2014). Suyatno (Kemendikbud, 2014) menyatakan bahwa PBL adalah proses pembelajaran berdasarkan masalah kehidupan nyata, siswa dirangsang untuk mempelajari masalah berkaitan dengan pengetahuan dan pengalaman yang mereka miliki sebelumnya (prior knowledge) untuk membentuk pengetahuan dan pengalaman baru. Siswa bekerja secara berkelompok untuk mencari solusi dari permasalahan dunia nyata.

Berdasarkan keunggulan yang terdapat pada PBL, maka peneliti melakukan penelitian eksperimen semu (quasi experiment) untuk melihat efektivitas penerapan model PBL terhadap peningkatan hasil belajar siswa kelas XI-MIPA SMAN 8 Pekanbaru pada semester ganjil Tahun Pelajaran 2019/2020. pada materi pokok Matriks. Penelitian ini melibatkan dua kelas yaitu satu kelas eksperimen dan satu kelas kontrol. Kelas eksperimen mendapatkan perlakuan berupa penerapan model PBL dan kelas kontrol menerapkan pembelajaran konvensional dengan pendekatan saintifik. Pemilihan materi Matriks dilakukan karena berdasarkan wawancara dengan guru matematika kelas XIMIPA SMAN 8 Pekanbaru ditemukan fakta bahwa siswa banyak mengalami kesulitan dalam memahami materi Matriks. 


\section{METODE}

Desain quasi eksperiment yang digunakan dalam penelitian ini adalah The Nonequivalent Pretest-Posttest Control Group Design (Lestari dan Yudhanegara, 2017) seperti terlihat pada Tabel 1 berikut.

Tabel 1. The Nonequivalent Pretest-Posttest Control Group Design

\begin{tabular}{lccc}
\hline Kelompok & Pretest & Perlakuan & Posttest \\
\hline Eksperimen & $\mathrm{O}_{1}$ & $X$ & $\mathrm{O}_{2}$ \\
Kontrol & $\mathrm{O}_{1}$ & - & $\mathrm{O}_{2}$ \\
\hline
\end{tabular}

Sumber: (Sukmadinata, 2012)

Pemilihan kelas sampel dilakukan dengan menggunakan metode purposive sampling yaitu memilih dua kelas dari sembilan kelas populasi berdasarkan jadwal yang tidak beririsan dan guru matematika yang sama, dan diperoleh kelas XI-MIPA 3 , XI$\mathrm{MIPA}_{4}$, dan XI-MIPA 5. Setiap kelas terdiri dari 36 siswa. Berdasarkan informasi dari guru matematika, kelas $\mathrm{XI}^{-M I P A_{5}}$ memiliki kemampuan yang lebih tinggi dibandingkan kelas XI-MIPA ${ }_{3}$ dan XI-MIPA4. Peneliti disarankan untuk memilih kelas XI-MIPA $\mathrm{A}_{3}$ dan $\mathrm{XI}^{-M I P A}{ }_{4}$ sebagai sampel penelitian karena memiliki kemampuan yang relatif sama. Peneliti melakukan pemilihan secara acak untuk menentukan kelas eksperimen dan kelas kontrol. Dari hasil pemilihan tersebut, kelas $\mathrm{XI}_{-M I P A_{3}}$ menjadi kelas kontrol dan kelas XI$\mathrm{MIPA}_{4}$ menjadi kelas eksperimen.

Data peningkatan hasil belajar matematika siswa diperoleh dari skor pretest dan posttest pada aspek pengetahuan dan keterampilan. Untuk menganalisis peningkatan hasil belajar matematika siswa digunakan data $N$-Gain. Data $N$-Gain atau normalized gain (gain ternormalisasi) merupakan data yang diperoleh dengan membandingkan selisih skor posttest dan pretest dengan selisih Skor Maksimum Ideal (SMI). Nilai $\mathrm{N}$-gain ditentukan dengan menggunakan rumus berikut:

$N-$ gain $=\frac{\text { skor posttest }- \text { skor pretest }}{\text { SMI }- \text { skor pretest }}$

Terhadap data $\mathrm{N}$-gain hasil belajar matematika siswa kelas eksperimen dan kelas kontrol dilakukan uji perbedaan dua rata-rata yang didahului dengan uji normalitas dan uji homogenitas varians. Analisis ini dilakukan untuk melihat apakah peningkatan hasil belajar matematika siswa kelas eksperimen lebih tinggi dari kelas kontrol. Analisis dilakukan dengan bantuan perangkat lunak SPSS for Windows Versi 23.

\section{HASIL DAN PEMBAHASAN}

Analisis peningkatan hasil belajar pada skor penilaian pengetahuan dilakukan dengan menguji perbedaan rata-rata skor peningkatan $(\mathrm{N}$-Gain) siswa kedua kelas sampel. Analisis data peningkatan skor penilaian pengetahuan dilakukan untuk menguji hipotesis: "Siswa yang dibelajarkan dengan model Problem Based Learning memiliki peningkatan hasil belajar yang lebih baik daripada siswa yang dibelajarkan melalui pembelajaran konvensional dengan pendekatan saintifik". Sebelum melakukan uji tersebut, terlebih dahulu dilakukan uji normalitas data skor peningkatan hasil belajar matematika siswa $(\mathrm{N}$ Gain) kedua kelas sampel. Hasil uji normalitas data menggunakan uji Liliefors dapat dilihat dalam Tabel 2 berikut.

Tabel 2. Hasil Uji Normalitas Skor $N$-Gain Kelas Eksperimen dan Kontrol dengan SPSS for Windows Versi 23 untuk Penilaian Pengetahuan

\begin{tabular}{lccccc}
\hline \multirow{2}{*}{ Kelas } & \multicolumn{5}{c}{ Liliefors } \\
\cline { 2 - 6 } & N & Mean & $\begin{array}{c}\text { Std. } \\
\text { Dev }\end{array}$ & Sig. & Ho \\
\hline Kontrol & 36 & 0,456 & 0,269 & 0,166 & Diterima \\
Eksperimen & 36 & 0,740 & 0,222 & 0,029 & Ditolak \\
\hline
\end{tabular}

Hasil uji normalitas berdasarkan Tabel 2 menunjukkan bahwa skor $N$-Gain siswa kelas eksperimen tidak berdistribusi normal, maka uji perbedaan dua rata-rata dilakukan dengan uji nonparametrik Mann Whitney. Berdasarkan rata-rata skor peningkatan hasil belajar matematika pada skor penilaian pengetahuan kelas sampel, terjadi peningkatan hasil belajar matematika pada kelas kontrol sebesar 0,456 dan pada kelas eksperimen sebesar 0,740. Sesuai kriteria yang dikemukakan oleh Hake (Lestari \& Yudhanegara, 2017) peningkatan hasil belajar matematika pada skor penilaian pengetahuan pada kelas kontrol tergolong 
peningkatan yang sedang dan pada kelas eksperimen tergolong tinggi. Hasil uji MannWhitney dengan SPSS dari data skor $N$-Gain siswa kelas eksperimen dan posttest siswa kelas kontrol disajikan pada Tabel 3 berikut.

Tabel 3. Hasil Uji Perbedaan Dua Rata-rata Skor $N$-Gain Kelas Eksperimen dan Kontrol dengan SPSS for Windows Versi 23 untuk Penilaian Pengetahuan

\begin{tabular}{lccccc}
\hline Kelas & $\begin{array}{c}\text { Mean } \\
\text { Ranks }\end{array}$ & $\begin{array}{c}\text { Sum of } \\
\text { Ranks }\end{array}$ & $\mathbf{Z}$ & $\begin{array}{c}\text { Sig. } \\
(\mathbf{2 -} \\
\text { tailed) }\end{array}$ & $\mathbf{H}_{\mathbf{0}}$ \\
\hline Kontrol & 26,47 & 953,00 & - & 0.000 & Ditolak \\
Eksperimen & 46,53 & 1675,00 & 4,072 & & \\
\hline
\end{tabular}

Nilai sig. yang diperoleh dari SPSS adalah sig.2-tailed (dua arah), menurut Widhiarso (dalam Nopriana, 2015) jika $\frac{1}{2} \operatorname{sig} \cdot(2-$ arah $)=\operatorname{sig} .(1-$ arah $)>0.05$ maka $H_{0}$ diterima, dalam hal lainnya $H_{0}$ ditolak. Berdasarkan Tabel 3 terlihat bahwa nilai significance (sig.) sebesar 0.000. Ini menunjukkan bahwa pada tingkat kepercayaan $95 \%$, rata-rata skor $N$-Gain siswa kelas eksperimen lebih tinggi daripada skor $N$-Gain kelas kontrol. Dengan kata lain, peningkatan hasil belajar matematika pada skor penilaian pengetahuan kelas eksperimen lebih tinggi dari kelas kontrol.

Analisis peningkatan hasil belajar siswa pada skor penilaian keterampilan dilakukan dengan menguji perbedaan rata-rata skor peningkatan (N-Gain) siswa kedua kelas sampel. Analisis data peningkatan skor penilaian keterampilan dilakukan untuk menguji hipotesis: "Siswa yang dibelajarkan dengan model Problem Based Learning memiliki peningkatan hasil belajar yang lebih baik daripada siswa yang dibelajarkan melalui pembelajaran konvensional dengan pendekatan saintifik".

Sebelum melakukan uji tersebut, terlebih dahulu dilakukan uji normalitas data skor peningkatan hasil belajar matematika siswa ( $N$-Gain) kedua kelas sampel. Hasil uji normalitas data menggunakan uji Liliefors dapat dilihat dalam Tabel 4 berikut.
Tabel 4. Hasil Uji Normalitas Skor N-Gain Kelas Eksperimen dan Kontrol dengan SPSS for Windows Versi 23 untuk Penilaian Keterampilan

\begin{tabular}{lccccc}
\hline \multirow{2}{*}{ Kelas } & N & \multicolumn{4}{c}{ Liliefors } \\
\cline { 3 - 6 } & & Mean & $\begin{array}{c}\text { Std. } \\
\text { Dev }\end{array}$ & Sig. & $\mathbf{H}_{\mathbf{0}}$ \\
\hline Kontrol & 36 & 0,477 & 0,176 & 0,200 & Diterima \\
Eksperimen & 36 & 0,691 & 0,232 & 0,010 & Ditolak \\
\hline
\end{tabular}

Hasil uji normalitas berdasarkan Tabel 4 menunjukkan bahwa skor $\mathrm{N}$-Gain siswa kelas eksperimen tidak berdistribusi normal, maka uji perbedaan dua rata-rata dilakukan dengan uji nonparametrik Mann Whitney. Berdasarkan rata-rata skor peningkatan hasil belajar matematika pada skor penilaian keterampilan kelas sampel, terjadi peningkatan pada kelas kontrol sebesar 0,477 dan pada kelas eksperimen sebesar 0,691. Sesuai kriteria yang dikemukakan oleh Hake (Lestari \& Yudhanegara, 2017) peningkatan hasil belajar matematika pada skor penilaian keterampilan pada kelas kontrol tergolong peningkatan yang sedang dan pada kelas eksperimen tergolong tinggi. Hasil uji Mann-Whitney dengan SPSS dari data skor $N$-Gain siswa kelas eksperimen dan posttest siswa kelas kontrol disajikan pada Tabel 5 berikut.

Tabel 5. Hasil Uji Perbedaan Dua Rata-rata Skor $N$-Gain Kelas Eksperimen dan Kontrol dengan SPSS for Windows Versi 23 untuk Penilaian Keterampilan

\begin{tabular}{lccccc}
\hline Kelas & $\begin{array}{c}\text { Mean } \\
\text { Ranks }\end{array}$ & $\begin{array}{c}\text { Sum of } \\
\text { Ranks }\end{array}$ & $\mathbf{Z}$ & $\begin{array}{c}\text { Sig. } \\
\mathbf{( 2 -} \\
\text { tailed) }\end{array}$ & $\mathbf{H}_{\mathbf{0}}$ \\
\hline $\begin{array}{l}\text { Kontrol } \\
\text { Eksperimen }\end{array}$ & 27,13 & 976,50 & 3,803 & 0.000 & Ditolak \\
\hline
\end{tabular}

Berdasarkan Tabel 5 terlihat bahwa nilai significance (sig.) sebesar 0.000 , yang berarti bahwa pada tingkat kepercayaan $95 \%$, rata-rata skor $N$-Gain siswa kelas eksperimen lebih tinggi daripada skor $N$-Gain siswa kelas kontrol. Dengan kata lain, peningkatan hasil belajar matematika pada skor penilaian keterampilan kelas eksperimen lebih tinggi dari kelas kontrol. 
Proses pembelajaran di kelas eksperimen dilakukan dengan menerapkan model Problem Based Learning (PBL), dimana pada setiap pertemuan masing-masing siswa memperoleh Lembar Aktivitas Siswa (LAS) yang berguna untuk mengarahkan siswa dalam menyelesaikan permasalahan dengan menggunakan tahap-tahap dalam model PBL. Siswa pada kelas eksperimen dibagi menjadi sembilan kelompok yang masingmasing kelompok terdiri dari empat siswa dengan kemampuan heterogen. Materi yang dipelajari setiap pertemuan adalah: 1) Konsep matriks, ordo, jenis, dan kesamaan dua matriks; 2) Penjumlahan, pengurangan, dan perkalian skalar dengan matriks; 3) Perkalian matriks; dan 4) Transpose matriks.

Proses pembelajaran dengan menggunakan model PBL yang diterapkan di kelas eksperimen membuat siswa berpartisipasi aktif dalam menyelesaikan permasalahan kontekstual yang disajikan di dalam LAS secara berkelompok. Pembelajaran tersebut dilaksanakan pada lima tahapan yaitu 1) Orientasi siswa pada masalah; 2) Mengorganisasi siswa untuk belajar; 3) Membimbing penyelidikan individual maupun kelompok; 4) Mengembangkan dan menyajikan hasil karya; dan 5) Menganalisis dan mengevaluasi proses pemecahan masalah.

Pada tahap orientasi siswa terhadap masalah, masing-masing siswa membaca dan mencermati masalah yang disajikan dalam LAS. Pada tahap organisasi siswa untuk belajar, siswa menyampaikan berbagai pertanyaan seputar permasalahan yang akan dipecahkan. Selanjutnya, pada tahap ketiga yaitu melakukan penyelidikan mandiri dan kelompok, siswa dibimbing untuk mengumpulkan informasi guna memecahkan permasalahan pada LAS dengan cara berdiskusi di dalam kelompoknya. Siswa aktif mencari informasi dengan cara membaca buku siswa dan sumber lainnya serta aktif berdiskusi. Siswa kemudian mengasosiasi data-data tersebut untuk memecahkan masalah pada LAS. Setelah siswa memecahkan masalah yang terdapat pada LAS, siswa menuliskan kesimpulan dari penyelesaian masalah. Selanjutnya siswa menyajikan dan mempresentasikan hasil pemecahan masalahnya di depan kelas secara tertulis dan lisan. Pada tahap terakhir, siswa difasilitasi oleh guru untuk melakukan refleksi terhadap penyelidikan dan proses pemecahan masalah yang mereka lakukan. Guru melakukan tanyajawab untuk mengonfirmasi, memberikan tambahan informasi, maupun melengkapi informasi yang diperlukan siswa.

Pada kelas eksperimen yang menerapkan pembelajaran dengan model PBL, siswa memecahkan masalah matematis dengan berdiskusi kelompok, sehingga siswa dituntut untuk berpartisipasi aktif dalam proses pembelajaran. Selain itu, LAS memuat masalah nyata sehingga membuat siswa penasaran dan termotivasi untuk memecahkan masalah dengan beragam cara. Dengan adanya aktivitas ini, siswa dapat membangun pengetahuannya sendiri, membangkitkan potensinya untuk menggunakan kemampuan berpikirnya dalam memecahkan masalah.

Terjadinya peningkatan hasil belajar siswa disebabkan karena pelaksanaan model PBL telah memberi kesempatan kepada setiap siswa untuk memiliki pemahaman terhadap materi pelajaran dan meningkatkan partisipasi mereka dalam diskusi kelompok. Siswa berpartisipasi aktif menemukan pengetahuannya sendiri sehingga pembelajaran menjadi bermakna dan pengetahuan yang diperoleh bertahan lama (Hosnan, 2016). Karena pembelajaran dilakukan secara berkelompok sehingga membuat siswa aktif bekerja sama dan meningkatkan rasa tanggung jawab dalam memecahkan masalah.

Pada kelas kontrol, peneliti menerapkan pembelajaran konvensional dengan pendekatan saintifik yang terdiri dari lima kegiatan pokok yaitu mengamati, menanya, mengumpulkan informasi, mengasosiasi dan mengkomunikasikan. Proses pembelajaran dilakukan tidak dengan berdiskusi dalam kelompok melainkan dengan kemampuannya masing-masing (individual). Peneliti banyak memberikan arahan pada masing-masing siswa maupun secara klasikal di dalam kelas. Pada saat siswa diminta untuk mempresentasikan jawaban di depan kelas, hanya siswa yang berkemampuan tinggi yang menawarkan dirinya untuk mempresentasikan jawabannya. 
Pada saat pengoreksian jawaban tes hasil belajar matematika, ditemukan bahwa banyak siswa yang kurang teliti dalam melakukan operasi hitung sehingga jawaban yang dituliskan kurang tepat, beberapa siswa juga kurang teliti dalam menyatakan ulang konsep sehingga banyak terjadi kesalahan serta ada beberapa siswa yang salah dalam mengaitkan konsep. Berikut adalah salah satu jawaban siswa di kelas kontrol pada soal nomor 5.

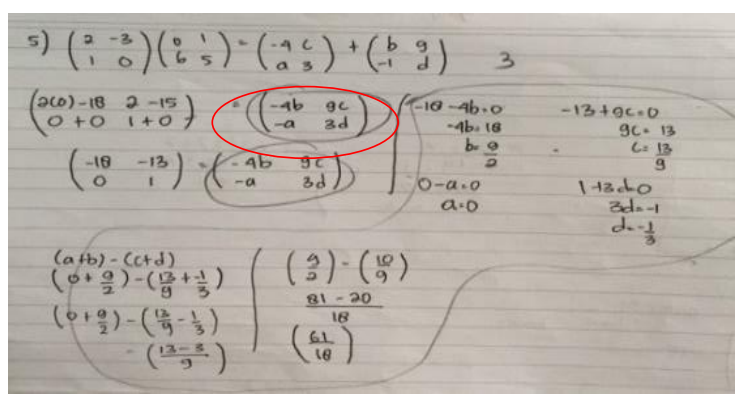

Gambar 1. Jawaban Siswa-1 pada Kelas Kontrol

Pada Gambar 1 terlihat kesalahan siswa dalam melakukan operasi penjumlahan pada matriks. Kesalahan juga terjadi di kelas eksperimen pada soal yang sama.

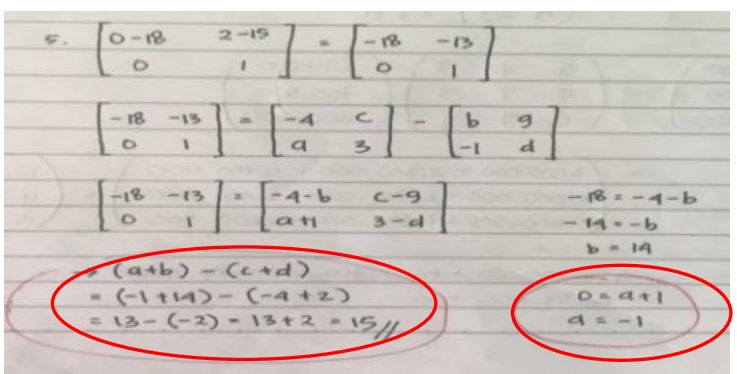

Gambar 2. Jawaban Siswa-1 pada Kelas Eksperimen

Berdasarkan Gambar 2, siswa sudah tepat dalam menggunakan operasi penjumlahan dan perkalian pada matriks serta tidak terdapat kesalahan pada operasi hitung sehingga masalah terselesaikan dengan baik. Contoh lain terlihat pada hasil jawaban salah satu siswa di kelas eksperimen pada soal nomor 7 .

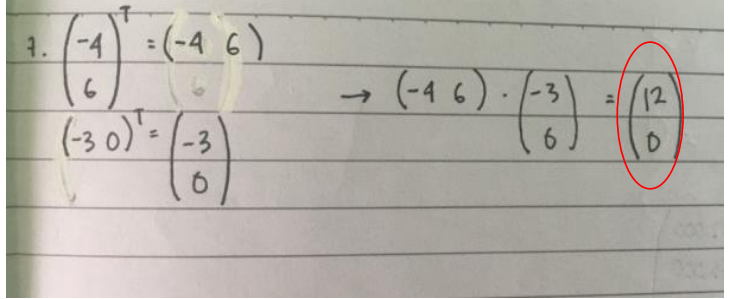

Gambar 3. Jawaban Siswa-2 pada Kelas Eksperimen

Berdasarkan jawaban siswa pada Gambar 3, siswa sudah tepat dalam melakukan transpose matriks dan operasi perkalian pada matriks. Akan tetapi siswa masih salah dalam menuliskan jawaban akhir. Sedangkan pada kelas kontrol, siswa sudah tepat dalam melakukan transpose pada matriks. Akan tetapi, siswa salah dalam melakukan operasi perkalian pada matriks sehingga jawaban tidak terselesaikan dengan baik. Berikut gambar hasil jawaban salah satu siswa di kelas kontrol pada soal yang sama.

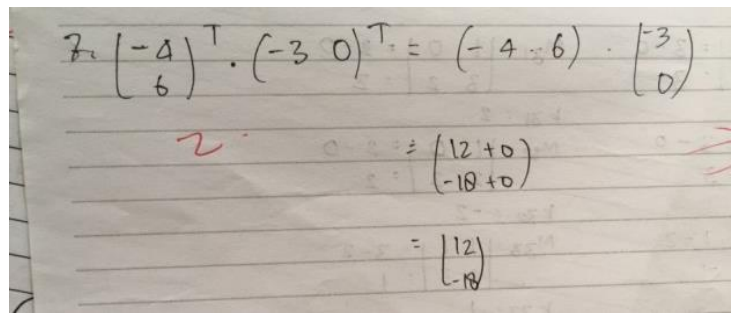

Gambar 4. Jawaban Siswa-2 pada Kelas Kontrol

Efektivitas yang peneliti tinjau dari penelitian ini adalah dengan melakukan analisis terhadap skor peningkatan hasil belajar matematika siswa ( $N$-Gain). Skor peningkatan hasil belajar matematika siswa dianalisis menggunakan uji Mann Whitney dengan menggunakan bantuan aplikasi SPSS for Windows Versi 23. Hasil analisis peningkatan data hasil belajar matematika menunjukkan bahwa rata-rata skor $N$-Gain penilaian pengetahuan dan penilaian keterampilan kelas eksperimen lebih tinggi daripada rata-rata skor $\mathrm{N}$-Gain penilaian pengetahuan dan penilaian keterampilan kelas kontrol. Selanjutnya, peneliti meninjau efektivitas penerapan model PBL dengan melakukan analisis terhadap skor peningkatan hasil belajar matematika siswa $(N$ Gain). Skor peningkatan hasil belajar matematika siswa dianalisis menggunakan uji 
Mann Whitney dengan menggunakan bantuan aplikasi SPSS for Windows Versi 23. Hasil analisis menunjukkan nilai significance (sig.) sebesar 0.000 . Hal ini menunjukkan bahwa $H_{0}$ ditolak dan $H_{1}$ diterima yang artinya peningkatan hasil belajar matematika siswa yang mengikuti pembelajaran dengan model PBL lebih tinggi daripada siswa yang mengikuti pembelajaran konvensional dengan pendekatan saintifik.

Berdasarkan rata-rata skor peningkatan hasil belajar matematika pada skor penilaian pengetahuan kelas sampel, terjadi peningkatan hasil belajar matematika untuk skor penilaian pengetahuan pada kelas kontrol sebesar 0,456 dan pada kelas eksperimen sebesar 0,740. Sementara itu, rata-rata skor peningkatan hasil belajar matematika untuk skor penilaian keterampilan pada kelas kontrol sebesar 0,477 sedangkan pada kelas eksperimen sebesar 0,691 . Berdasarkan kriteria yang dikemukakan oleh Hake (Lestari \& Yudhanegara, 2017) peningkatan hasil belajar matematika pada skor penilaian pengetahuan dan keterampilan pada kelas kontrol tergolong peningkatan yang sedang, sedangkan peningkatan yang terjadi di kelas eksperimen untuk skor penilaian pengetahuan tergolong tinggi dan untuk skor penilaian keterampilan tergolong sedang.

Penerapan model PBL telah memberikan kesempatan pada siswa untuk aktif dalam proses pembelajaran di antaranya menanggapi motivasi dan apersepsi, diskusi LAS dalam kelompok, terlatih dalam menyelesaikan soal non-rutin, dan berani menyampaikan pendapat serta mengajukan pertanyaan kepada guru. Sejalan dengan apa yang dikatakan oleh Sanjaya (2011) bahwa pemberian tindakan di dalam kelas dikatakan berhasil jika masalah yang dikaji semakin mengerucut atau melalui tindakan masalah semakin terpecahkan; dilihat dari aspek hasil belajar siswa dari skor pretest dan posttest yang semakin meningkat.

Hasil dari penelitian ini sejalan dengan hasil dari penelitian yang dilakukan oleh Farida (2018) yang menyebutkan bahwa hasil belajar matematika siswa yang diberikan model pembelajaran PBL cenderung lebih baik dari hasil belajar matematika siswa yang diberikan model pembelajaran konvensional dengan pendekatan saintifik. Hasil penelitian Widyani dan Slamet (2015) juga mengungkapkan hal senada, bahwa siswa yang dibelajarkan melalui penerapan model PBL memiliki peningkatan hasil belajar matematika yang lebih tinggi daripada siswa yang dibelajarkan melalui pembelajaran konvensional.

Dari paparan di atas dapat disimpulkan bahwa pada tingkat kepercayaan 95\%, secara signifikan siswa yang dibelajarkan melalui penerapan model PBL memiliki peningkatan hasil belajar matematika yang lebih tinggi daripada siswa yang dibelajarkan melalui pembelajaran konvensional dengan pendekatan saintifik.

\section{SIMPULAN}

Dari hasil penelitian ini dapat disimpulkan bahwa:

1. Peningkatan hasil belajar matematika siswa yang mengikuti pembelajaran dengan model PBL lebih baik daripada siswa yang mengikuti pembelajaran konvensional dengan pendekatan saintifik untuk skor penilaian pengetahuan.

2. Peningkatan hasil belajar matematika siswa yang mengikuti pembelajaran dengan model PBL lebih baik daripada siswa yang mengikuti pembelajaran konvensional dengan pendekatan saintifik untuk penilaian keterampilan.

\section{REKOMENDASI}

Melalui penelitian yang telah dilakukan, peneliti mengemukakan rekomendasi yang berhubungan dengan penerapan model PBL dalam pembelajaran matematika.

1. PBL merupakan salah satu model pembelajaran yang memperkenalkan siswa dengan matematika melalui permasalahan dalam kehidupan sehari-hari

2. Pada model PBL, siswa dituntut agar dapat memecahkan masalah kontekstual yang diberikan, tetapi membutuhkan waktu yang lebih lama. Bagi guru atau peneliti yang ingin menerapkan model PBL harus dapat membimbing dan mengarahkan siswa dengan maksimal selama proses pembelajaran. 
Volume 2, Nomor 2, Mei 2020

DOI: https://doi.org/10.33578/prinsip.v2i2.56

jprinsip.ejournal.unri.ac.id

\section{DAFTAR PUSTAKA}

Farida, R. (2018). Penerapan pembelajaran matematika dengan Model Problem Based Learning terhadap hasil belajar matematika ditinjau dari kreativitas siswa kelas VII SMP Negeri 2 Baki Sukoharjo. FKIP Universitas Muhammadiyah Surakarta

Hosnan. (2016). Psikologi perkembangan peserta didik. Ghalia Indonesia

Kemendikbud. (2014). Salinan Lampiran Permendikbud No. 59 Tahun 2014 Tentang Kurikulum 2013 Sekolah Menengah Atas/Madrasah Aliyah. Kemendikbud

Kemendikbud. (2018). Hasil UN SMA tahun 2018. [Online]. Tersedia di: https://kemdikbud.go.id/main/files/downl oad/9c7fdf36a39328d [diakses 4 Januari 2019]

Kemendiknas. (2007). Salinan Lampiran Peraturan Menteri Pendidikan Nasional No. 20 Tentang Standar Penilaian Pendidikan. Kemendiknas

Lestari, K.E. \& Yudhanegara, M.R. (2017). Penelitian pendidikan matematika. Refika Aditama
Nafiah, Y.N. \& Suyanto, W. (2014). Penerapan Model Problem Based Learning untuk meningkatkan keterampilan berpikir kritis dan hasil belajar siswa. Jurnal Pendidikan Vokasi, 4(1), $\quad 125$ 143. https://doi.org/10.21831/jpv.v4i1.25 40

Nopriana, T. (2015). Disposisi matematis siswa melalui Model Pembelajaran Geometri Van Hiele. Jurnal Fibonacci, 1(2), 80-94. https://doi.org/10.24853/fbc.1.2.80-94

OECD. (2018). PISA 2015 Result in focus. Columbia University

Pribadi, B.A. (2010). Model desain sistem pembelajaran. Dian Rakyat

Sanjaya, W. (2011). Penelitian tindakan kelas. Prenada Media

Sukmadinata, N.S. (2012). Metode penelitian pendidikan. Remaja Rosdakarya

Widyani, A. (2015). Peningkatan kreativitas dan hasil belajar matematika dengan Model Pembelajaran Problem Based Learning berbasis Macromedia Flash (PTK pada siswa kelas VII SMP Muhammadiyah 10 Surakarta semester genap tahun ajaran 2014/2015). Skripsi pada Universitas Muhammadiyah Surakarta (tidak diterbitkan) 